\title{
Influence of gender and physical exercise on balance of healthy young adults
}

\author{
Influência do sexo e do exercício físico no \\ equilíbrio de jovens saudáveis
}

\author{
Sarina Francescato Torres ${ }^{[a]}$, Júlia Guimarães Reis ${ }^{[\mathrm{b}]}$, Daniela Cristina Carvalho de Abreu ${ }^{[c]}$ \\ [a] Graduate, Universidade de São Paulo, Faculdade de Medicina de Ribeirão Preto, Ribeirão Preto, SP - Brazil, e-mail: \\ sarinaftorres@gmail.com \\ [b] PhD, Universidade de São Paulo, Faculdade de Medicina de Ribeirão Preto, Ribeirão Preto, SP - Brazil, e-mail: \\ juliagreis@yahoo.com.br \\ [c] PhD, professor, Universidade de São Paulo, Faculdade de Medicina de Ribeirão Preto, Ribeirão Preto, SP - Brazil, e-mail: \\ dabreu@usp.br
}

\begin{abstract}
Objective: To verify the effects of gender and physical activity on postural sway. Method: A cross-sectional study was conducted to analyze upright balance of young men and women between the ages of 20-30, both active and sedentary. Study participants were 60 individuals, who were divided into: active women ( $\mathrm{n}=$ $15)$, sedentary women $(n=15)$, active men $(n=15)$ and sedentary men $(n=15)$. The International Physical Activity Questionnaire (IPAQ) short form, was used to evaluate each participant's level of physical activity. According to the questionnaire, active individuals are those who carry out moderate activity, with an energy expenditure between 3.5 and 6 METs (1 MET: $3.5 \mathrm{ml} / \mathrm{kg} / \mathrm{min}$ ), or vigorous activity, with an energy expenditure above 6 METs, at least three days a week for 20 minutes. To assess control of postural sway, we measured the amplitude and velocity of anteroposterior (AP) and mediolateral (ML) sway in standing position, with their eyes open and closed, with and without foam, on a force platform. Results: Comparison between genders revealed that, when compared to sedentary women, sedentary men displayed poorer performance in velocity and amplitude of AP postural control sway with their eyes closed, with and without foam. There were no differences in the amplitude and velocity of ML sway, both with open and closed eyes among groups $(\mathrm{p}<0.05)$. There were no differences when comparing physically active men and women
\end{abstract}


either. Conclusion: Sedentary men seem to rely more on vision for maintaining postural control in quiet standing situations with respect to women.

Keywords: Young adult. Motor activity. Postural balance. Sex.

\section{Resumo}

Objetivo: Verificar a relação da oscilação postural entre os sexos e a prática de atividade física. Método: Estudo transversal que analisou o equilíbrio semi-estático de homens e mulheres jovens entre 20 e 30 anos, ativos e sedentários. Foram incluídos 60 adultos, que foram divididos em: mulheres ativas $(n=15)$, mulheres sedentárias $(n=15)$, homens ativos $(n=15)$ e homens sedentários $(n=15)$. Para avaliar o nível de atividade física foi utilizado o Questionário Internacional de Atividade Física (IPAQ) versão curta, que considerou ativos aqueles que realizaram atividade moderada, com gasto de 3,5 a 6 METs (1 MET: 3,5 ml/ $\mathrm{kg} / \mathrm{min}$ ), ou vigorosa, com gasto superior a $6 \mathrm{METS}$, ao menos 3 dias por semana durante 20 minutos. Para avaliação do controle postural, a amplitude e velocidade de oscilação anteroposterior (AP) e mediolateral (ML) foram obtidas por meio de plataforma de força, na posição ortostática, com os olhos abertos e fechados, com e sem a espuma. Resultados: Na comparação entre os sexos, os homens sedentários apresentaram pior desempenho de velocidade e amplitude do controle postural AP com os olhos fechados, com e sem espuma, quando comparados com as mulheres sedentárias. Não houve diferenças na amplitude e velocidade de oscilação $M L$, tanto de olhos abertos quanto fechados entre os grupos ( $p<0,05)$. Também não foram observadas diferenças na comparação entre sexos quando praticantes de exercícios físicos. Conclusão: Conclui-se então que, em situação de sedentarismo, o sexo masculino parece mais dependente da visão para a manutenção do controle postural em situações semi-estáticas comparado ao sexo feminino.

Palavras-chave: Adulto jovem. Atividade física. Equilíbrio postural. Sexo.

\section{Introduction}

Postural control involves a combination of stability and postural orientation, being necessary for maintaining a position in space, moving in a controlled and coordinated fashion, and carrying out functional activities of daily living $(1,2,3,4,5)$.

The ability to maintain balance while standing requires the sensory detection of the body movements through information received by the vestibular, visual and somatosensory system; the integration of sensory-motor information in the central nervous system; an appropriate motor response; and the planning and execution of movements to control the center of gravity over the base of support $(5,6,7)$.

Poor postural control is considered one of the main risk factors for falling and one of the few factors capable of being improved upon with therapeutic intervention (8) Thus, its role as one of the main domains of functional capacity is broadly acknowledged (9).

The most commonly used objective measure of postural control is the Center of Pressure (COP), defined as a point of application that is the sum of all vertical forces on the support surface. It is measured using a force platform (10).

Evidence indicates that physical exercise helps maintain an independent lifestyle, for it improves functional capacity and muscle strength, and consequently, contributes to preventing falls and associated lesions $(11,12)$. Preventing or reducing falls and lesions results in lower expenses with health care (13) for many of the risk factors for postural instability are related to inactivity (11). Factors such as amplitude of movement (AOM), power and fatigue resistance can affect an individual's capacity to respond effectively to a balance disturbance (14).

Nonetheless, it is still unclear whether physical exercise is beneficial for the postural control of young adults, or if this benefit is only relevant with age advancing. Furthermore, the influence of sex on postural stability also remains unclear.

Therefore, a better understanding about the influence of sex and physical exercise on postural control is important in order to establish reference 
data that allow for the early detection of individuals with balance disorders. They can then be referred to specific treatment directed at health promotion, leading to improved quality of life in the long term. Thus, the goal of the present study was to analyze semi-static balance during quiet standing position of young adults and to verify whether there are any differences in postural sway between sexes, as well as between sedentary and physically active individuals.

This study worked with the hypothesis that physical exercise is more influential than sex for improving postural control.

\section{Methods}

Subjects

The convenience sample comprised 60 active and sedentary young adults, aged 20-30 years. These individuals were assigned to one of four groups according to sex: Group $1(n=15)$ consisted of sedentary men; Group $2(\mathrm{n}=15)$, physically active men; Group $3(n=15)$, sedentary women and Group $4(n=15)$, active women.

Volunteers were recruited at the Ribeirão Preto School of Medicine, University of São Paulo (FMRPUSP) and in the community, throughout 2011. The study was approved by the local ethics committee (HCRP protocol no. 4131/2010), and all volunteers signed a free and informed consent form before participating in the research.

Data were collected at the Laboratory of Assessment and Rehabilitation of Equilibrium (L.A.R.E.) FMRP-USP. Upon entering the study, participants were measured in terms of weight and height and they answered the International Physical Activity Questionnaire (IPAQ) short form. According to this questionnaire, sedentary individuals are those who do not practice any physical exercise during the week; active are those who conduct moderate, with energy expenditure between 3.5 and 6 METs (1 MET: 3.5 $\mathrm{ml} / \mathrm{kg} / \mathrm{min}$ ) or vigorous activity, with energy expenditure greater than 6 METs, and who exercised at least three days a week for at least 20 minutes per session $(15,16)$.

Exclusion criteria was applied to individuals with a history of lesions and/or surgery of the inferior limbs; individuals affected by syndromes that affect balance and/or who took medication which compromised the integrity of the central and/or peripheral nervous system.

\section{Procedures}

Balance assessment was conducted on a force platform (EMG System do Brasil, São José dos Campos, Brazil). A signal acquisition frequency of $100 \mathrm{~Hz}$ (17) and a Butterworth fourth-order low-pass digital filter were used, with a cut-off frequency set at $10 \mathrm{~Hz}$.

Volunteers stood on the force platform barefoot, feet spread shoulder-length apart, arms alongside the body. The conditions for evaluating upright balance were: 1) Standing on a fixed wooden surface, eyes open (FPOE - fixed platform open eyes); 2) Standing on a fixed wooden surface, eyes closed (FPCE - fixed platform closed eyes); 3) Standing on foam (5cm height, $30 \mathrm{~g} / \mathrm{dm}^{3}$ density and $50 \mathrm{~cm} \times 50 \mathrm{~cm}$ dimensions), eyes open (UPOE - unstable platform open eyes); 4) Standing on foam eyes closed (UPCE - unstable platform closed eyes). Each condition was evaluated three times, for 30 seconds each, with a resting period between each attempt. In open eyes condition, the participant's gaze was to remain fixed on a circular point, $5 \mathrm{~cm}$ in diameter and $1.5 \mathrm{~m}$ away from the individual (17).

The amplitude and velocity of sway of COP in anteroposterior (AP) and mediolateral (ML) direction were registered, and the data were analyzed using the Matlab software (Math Works, Inc.).

\section{Statistical analysis}

The mixed-effect model (random and fixed effects) was used for statistical analysis and the assumption was that residuals would present normal distribution and constant variance. For intergroup analysis of upright balance, four models of mixed effect were applied using sex, group and conditions (FPOE, FPCE, UPOE, UPCE) as factors, and AP amplitude, ML amplitude, AP velocity, and ML velocity as dependent variables.

Anthropometric data were compared using Tukey's post-hoc test, and the value established for $\mathrm{p}$ was 0.05 .

The SAS software version 9.0 was used; the model was adjusted using PROC MIXED and the results were obtained via PROC GLM. 


\section{Results}

Univariate analysis did not result in any differences between the groups regarding age $[\mathrm{F}(3.56)=0.94$, $\mathrm{p}>0.05]$. However, there were differences between the weight $[\mathrm{F}(3.56)=14.73, \mathrm{p}<0.05]$ and height variables $[\mathrm{F}(3.56)=28.27, \mathrm{p}<0.05]$. The results of Tukey's post-hoc tests showed that men (both active and sedentary) presented greater height and weight than women (both active and sedentary). Table 1 presents the subject's general data.

For the most part, the active men practiced weight training - resistance exercise $(26.67 \%)$ and went to the gym - aerobic exercise + resistance exercise
$(26.67 \%)$ as their physical activity, whereas the active women (33.33\%) preferred running. (Figures $1 \mathrm{~A}$ and $1 \mathrm{~B})$.

When comparing the upright of the four groups, a significant difference was observed in AP amplitude $[p \leq 0.05]$ and AP velocity [ $\leq 0.05]$, in FPCE and UPCE conditions, when comparing sedentary men to sedentary women. Men presented greater AP sway amplitude and velocity than women (Figures $2 \mathrm{~A}$ and $3 \mathrm{~A}$ ).

In FPOE and UPOE conditions, no differences were observed between men and women, regarding AP and ML amplitude ( $p \geq 0.05)$, and AP and ML velocity $(p \geq 0.05)$, on any level of physical activity.

Table 1 - Characteristics of the groups, expressed in mean \pm standard deviation

\begin{tabular}{ccccc}
\hline Characteristics & $\begin{array}{c}\text { Sedentary Men } \\
\mathbf{n}=\mathbf{1 5}\end{array}$ & $\begin{array}{c}\text { Active Men } \\
\mathbf{n}=\mathbf{1 5}\end{array}$ & $\begin{array}{c}\text { Sedentary Women } \\
\mathbf{n}=\mathbf{1 5}\end{array}$ & $\begin{array}{c}\text { Active Women } \\
\mathbf{n}=\mathbf{1 5}\end{array}$ \\
\hline Age (years) & $22.53 \pm 2.42$ & $23.4 \pm 3.58$ & $22.87 \pm 2.85$ & $21.73 \pm 2.05$ \\
Weight $(\mathbf{K g})$ & $8512 \pm 18.62^{*}$ & $81.05 \pm 12.46^{*}$ & $60.04 \pm 9.0$ & $61.55 \pm 10.23$ \\
Height $(\mathbf{m})$ & $1.83 \pm 0.1^{*}$ & $1.78 \pm 0.07^{*}$ & $1.63 \pm 0.05$ & $1.65 \pm 0.07$ \\
\hline
\end{tabular}

Note: ${ }^{*} p<0.05$ compared to women (sedentary and active).

Source: Research data.

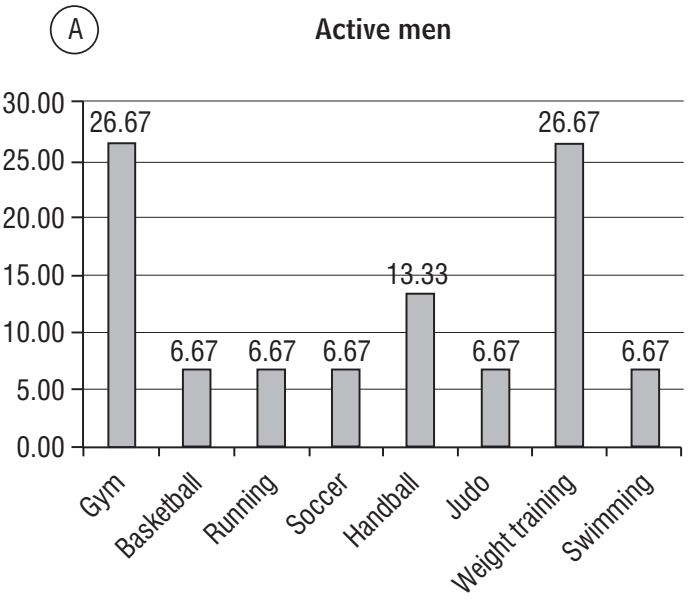

Percentage

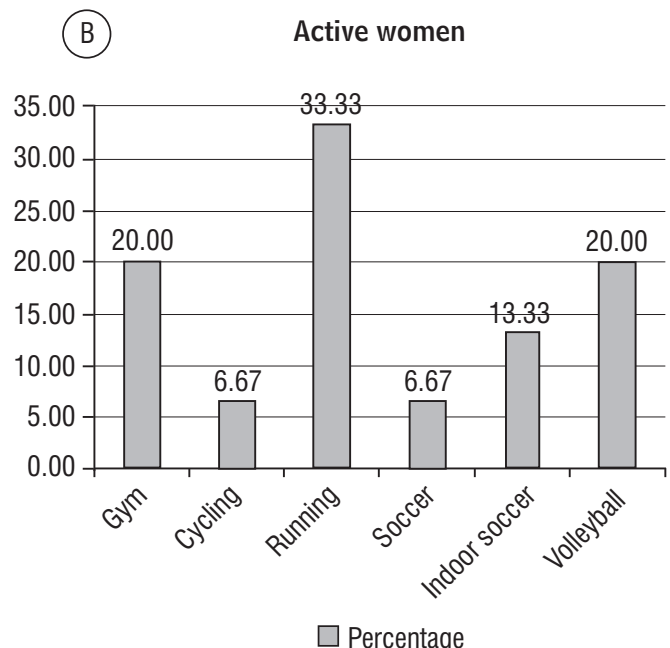

Percentage

Figure 1 - (A) Physical exercise in the physically active men group ( $n=15)$. (B) Physical exercise in the active women group $(\mathrm{n}=15)$

Source: Research data. 

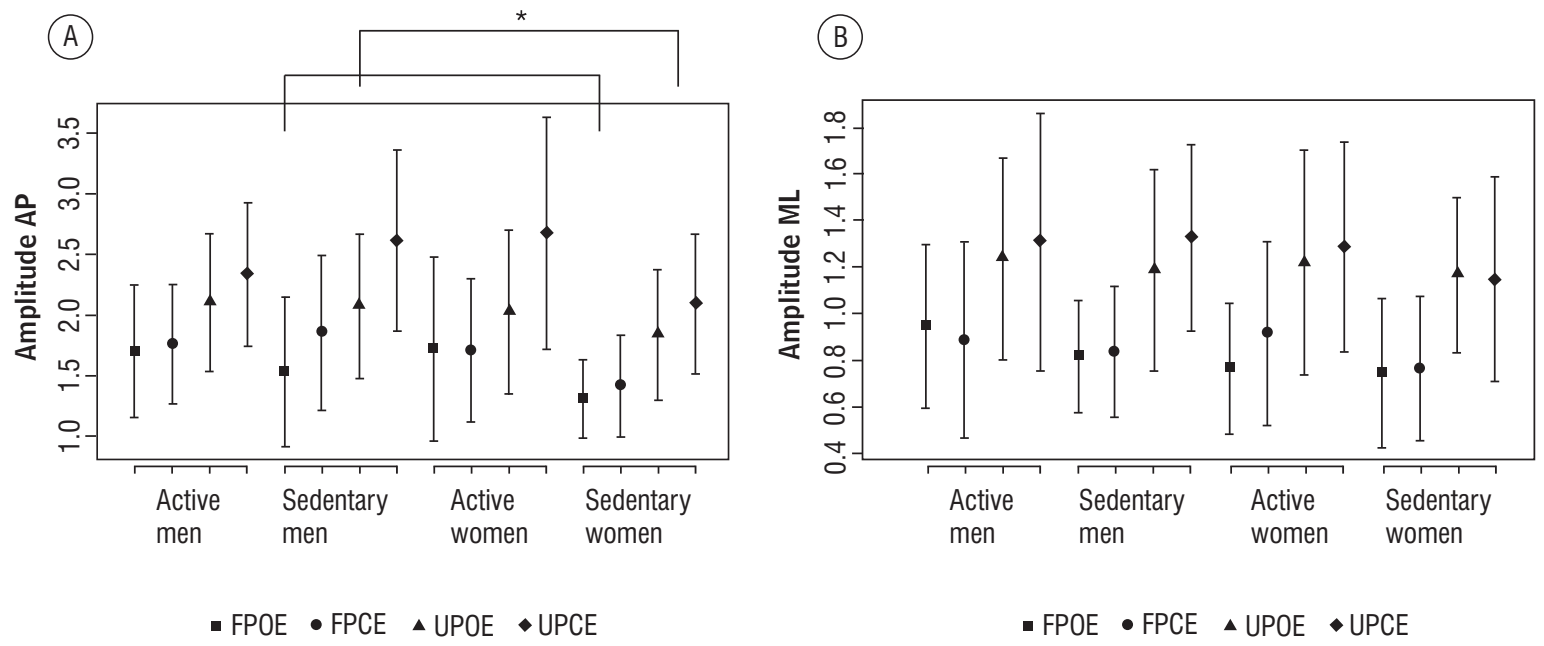

Figure 2 - (A) Mean values \pm SD of amplitude (cm) of COP in anteroposterior direction (AP) and (B) Mediolateral (ML) in FPOE conditions (fixed platform open eyes), FPCE (fixed platform closed eyes), UPOE (unstable platform open eyes), UPCE (unstable platform closed eyes) for all groups

Note: ${ }^{*} p<0.05$.

Source: Research data.

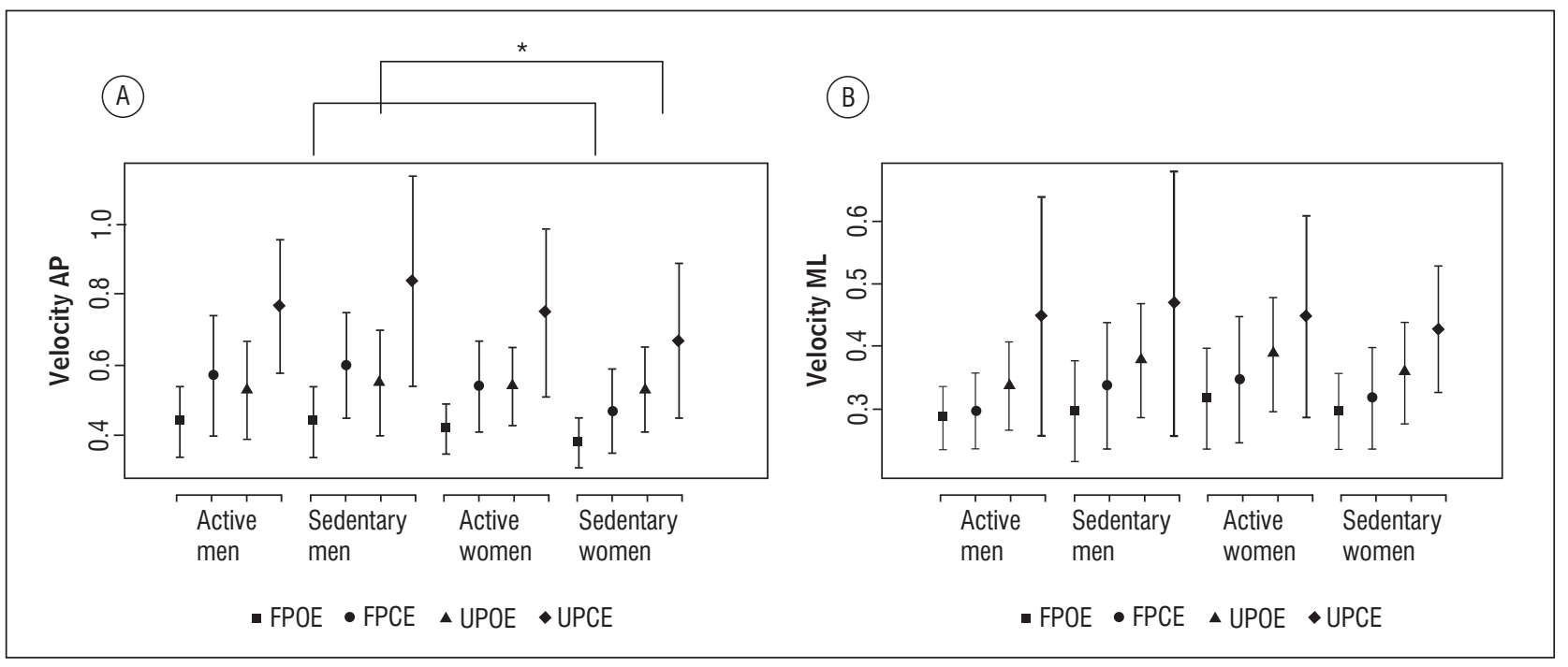

Figure 3 - (A) Values expressed in mean \pm SD of velocity $(\mathrm{cm} / \mathrm{s})$ of COP in anteroposterior (AP) and (B) Mediolateral (ML) direction in FPOE conditions (fixed platform open eyes), FPCE (fixed platform closed eyes), UPOE (unstable platform open eyes), UPCE (unstable platform closed eyes) for all groups

Note: ${ }^{*} p<0.05$.

Source: Research data.

\section{Discussion}

There is controversy surrounding whether or not there are differences between sexes regarding postural control of standing position with eyes open and closed $(18,19,20)$. Some suggest that, when sex differences do occur, they can be explained by vision factors, which appear to be more significant in men due to morphological characteristics $(21,22)$. 
The results of the present study show that when comparing sedentary individuals of both sexes, there were differences when in the FPCE (amplitude and velocity of AP displacement) and UPCE conditions (amplitude and velocity of AP displacement). Sedentary men presented higher values of AP amplitude and displacement velocity, with eyes closed, with respect to sedentary women. This finding suggests that vision greatly influences balance control among sedentary men, for depriving them of this sense worsened their body control performance.

However, it is important to consider that the men were taller than the women, and it is has been established that this factor contributes to poorer postural stability. Thus, it is possible that the balance differences found between men and women were a result of their anthropometric differences $(23,24,25)$.

Several other studies have demonstrated that visual deprivation and the imprecision of proprioceptive information increase center of pressure displacement $(26,27,28)$. Nonetheless, we were not able to find studies in the literature showing vision deprivation, with or without imprecision of proprioceptive information, to cause more negative impact on men than on women.

The results display differences between sexes in FPCE and UPCE situations only among sedentary individuals, being that inactivity caused a greater negative impact on the semi-static balance of men. These results do not corroborate those of a review study by Mann et al. (12) in which women were found to be more susceptible to imbalance, reporting a lack of studies to explain this finding. However, the results of the present study corroborate those of Abrahamová et al. (26), which also found significant differences between the semi-static balance of young men and women on stable surfaces with their eyes closed.

No differences were observed between sexes when the individuals were physically active. This finding suggests that physical exercise helps equalize the response of the postural control system of men in semi-static situations. This can be explained because physical exercise is capable of reducing visual dependency in postural control and also because it balances out the biomechanical disadvantage that men had regarding their height, with respect to women. Our results agree with those of a study conducted by Martins et al. (29), with physically active young individuals between 18 and 24 years. Their results found no significant differences between postural sway control in men and women.

Other studies have shown that regular physical exercise can contribute to improving muscle strength, minimizing existing balance disorders, besides reducing body sway due to its beneficial effect on the sensory and motor systems. However, a large part of these studies is conducted with older adults, or comparing younger and older adults (12), (30).

Our study did not display any significant results regarding ML amplitude and sway velocity among groups, only in the AP direction. This same finding was also presented in other studies, in which AP sway was greater not only in older individuals, but also in younger ones. This suggests that this variable is a good parameter for evaluating postural control, since some studies report subtle differences between the postural sway of older and younger adults (26), (31, $32,33,34)$.

Our results suggest that practicing physical exercise from an early age, especially for young men, seems to have a more positive impact on postural control performance when compared to women. However, studies relating continual physical exercise with the respective postural balance response must be developed to prove this.

Our results indicate the need of an early approach, in order to prevent possible loss of postural control, minimize health problems and risk of falls, for sharp decline of postural control increases the risk of falls and resulting fractures and immobilization. In the long term, this leads to older adults losing their autonomy and, consequently, reducing their quality of life. Thus, studies on balance in young adults with the intervention of physical exercise should always be progressing (12), (30).

\section{Limitations of the study}

Women's hormonal changes during pre- and postovulation periods were not taken into consideration. However, a study by Ericksen and Gribble (35) analyzed the hormonal variation of progesterone and estradiol in 20 healthy and physically active young women during pre- and post-ovulation. They found that hormonal fluctuations throughout the menstrual cycle did not affect dynamic postural control, and it is likely that the same occurred with semi-static 
control, for it is a pre-requisite for carrying out dynamic activities.

Another limitation of our study was that factors which contribute towards body imbalance were not evaluated, such as instability and ankle ligament laxity. A study by Beynnon et al. (36) obtained the same results as Ericksen and Gribble (35), in which women presented greater knee and ankle ligament laxity when compared to men. However, there was no relation to hormonal alterations. In our study, the postural control of women was not any poorer than that of men. Therefore, ligament laxity did not prove to be a relevant factor.

\section{Conclusion}

In conclusion, sedentary men presented poorer anteroposterior postural control with eyes closed when compared to sedentary women. However, there were no differences between sexes when they were physically active. Thus, practicing physical exercise early in life can be a form of early intervention, preventing possible losses in the postural control system and risk of falls as individuals age.

\section{Acknowledgements}

The authors would like to thank the Unit of Bioengineering (Ribeirão Preto School of Medicine, University of São Paulo - FMRP/USP); the collaboration of Érika Harumi Tanaka, Hildemberg Agostinho Rocha de Santiago and Matheus Machado Gomes, and the financial support provided by the São Paulo Research Foundation (FAPESP - process \#2007/57685-4 and 2010/08705-5).

\section{References}

1. Souza GS, Gonçalves DF, Pastre CM. Propriocepção cervical e equilíbrio: uma revisão. Fisioter Mov. 2006; 19(4):33-40.

2. Loth EA, Rossi AG, Cappellesso PC, Ciena AP. Avaliação da influência do sistema vestibular no equilíbrio de adultos jovens através de posturografia dinâmica foam-laser e plataforma de força. Semina Cienc Biol Saude. 2008;29(1):57-64.
3. Benjuya N, Melzer I, Kaplanski J. Aging-induced shifts from a reliance on sensory input to muscle cocontraction during balanced standing. J Gerontol A Biol Sci Med Sci. 2004;59(2):166-71.

4. Rogind H, Lykkegaard JJ, Bliddal H, DanneskioldSamsoe B. Postural sway in normal subjects aged 20-70 years. Clin Physiol Funct Imaging. 2003;23(3):171-6.

5. Du-Pasquier RA, Blanc Y, Sinnreich M, Landis T, Burkhard $\mathrm{P}$, et al. The effect of aging on postural stability: a cross sectional and longitudinal study. Neurophysiol Clin. 2003;33(5):213-8.

6. Greve J, Alonso A, Bordini ACPG, Camanho GL. Correlation between body mass index and postural balance. Clinics. 2007;62(6):717-20.

7. Aikawa AC, Braccialli LMP, Padula RS. Efeito das alterações posturais e de equilíbrio estático nas quedas de idosos institucionalizados. Rev Cienc Med. 2006; 15(3):189-96.

8. Choy NL, Brauer S, Nitz J. Changes in postural stability in women aged 20 to 80 years. J Gerontol A Biol Sci Med Sci. 2003;58(6):525-30.

9. Era P, Sainio P, Koskinen S, Haavisto P, Vaara M, et al. Postural balance in a random sample of 7,979 subjects aged 30 years and over. Gerontology. 2006; 52(4):204-13.

10. Melo PS, Ferreira TP, Santos-Pontelli TEG, Carneiro JAO, Carneiro AAO, Colafêmina JF. Comparação da oscilação postural estática na posição sentada entre jovens e idosos saudáveis. Rev Bras Fisioter. 2009;13(6):549-54.

11. Skelton AD. Effects of physical activity on postural stability. Age Ageing. 2001;30(Suppl. 4):33-9.

12. Mann L, Kleinpaul JF, Mota CB, Santos SG. Equilíbrio corporal e exercícios físicos: uma revisão sistemática. Motriz Rev Educ Fís. 2009;15(3):713-22.

13. Koceja DM, Allway D, Earles DR. Age differences in postural sway during volitional head movement. Arch Phys Med Rehabil. 1999;80(12):1537-41.

14. Faria JC, Machala CC, Dias RC, Dias JMD. Importância do treinamento de força na reabilitação da função muscular, equilíbrio e mobilidade de idosos. Acta Fisiatr. 2003;10(3):133-7. 
15. Pardini R, Matsudo SMM, Araújo T, Matsudo VKR, Andrade E, Braggion G, et al. Validação do questionário internacional de nível de atividade física (IPAQ Versão 6): estudo piloto em adultos jovens brasileiros. Rev Bras Cienc e Mov. 2001;9(3):45-51.

16. Azevedo MR, Araújo CLP, Reichert FF, Siqueira FV, Silva MC, Hallal PC. Gender differences in leisure-time physical activity. Int J Public Health. 2007;52(1):8-15.

17. Abreu DC, Gomes MM, de-Santiago HA, Herrero CF, Porto MA, Defino HL. What is the influence of surgical treatment of adolescent idiopathic scoliosis on postural control?. Gait Posture. 2012;36(3):586-90.

18. Steindl R, Kunz K, Schrott-Fischer A, Scholtz AW. Effect of age and sex on maturation of sensory systems and balance control. Dev Med Child Neurol. 2006; 48(6):477-82.

19. Lemos LFC, Teixeira CS, Mota CB. Uma revisão sobre centro de gravidade e equilíbrio corporal. R Bras Ci e Mov. 2009;17(4):83-90.

20. Kim JW, Eom GM, Kim CS, Kim DH, Lee JH, Park BK, et al. Sex differences in the postural sway characteristics of young and elderly subjects during quiet natural standing. Geriatr Gerontol Int. 2010;10(2):191-8.

21. Farenc I, Rougier P, Berger L. The influence of gender and body characteristics on upright stance. Ann Hum Biol. 2003;30(3):279-94.

22. Bryant EC, Trew ME, Bruce AM, Kuisma RME, Smith AW. Gender differences in balance performance at the time of retirement. Clin Biomech. 2005;20(3):330-5.

23. Kinney LaPier TL, Liddle S, Bain C. A comparison of static and dynamic standing balance in older men versus women. Canadian Physiotherapy. 1997;49:207-13.

24. Kejonen P. Body movement during postural stabilization (thesis). Oulu: University of Oulu; 2002.

25. Alonso AC, Luna NMS, Mochizuki L, Barbieri F, Santos S, Greve JM. The influence of anthropometric factors on postural balance: the relationship between body composition and posturographic measurements in young adults. Clinics. 2012;67(12):1433-41.

26. Abrahamová D, Hlavacka F. Age-related changes of human balance during quiet stance. Physiol Res. 2008; 57(6):957-64.
27. Yoon JJ, Yoon TS, Shin BM, Na EH. Factors affecting test results and standardized method in quiet standing balance evaluation. Ann Rehabil Med. 2012;36(1):112-8.

28. Lord SR, Menz HB: Visual contributions to postural stability in older adults. Gerontology. 2000;46(6):306-10.

29. Martins A, Pereira EF, Teixeira CS, Corazza ST. Relação entre força dinâmica máxima de membros inferiores e o equilíbrio corporal em praticantes de musculação. Rev Bras Cineantropom Desempenho Hum. 2010; 12(5):375-80.

30. Caldwell K, Harrison M, Adams M, Triplett NT. Effect of Pilates and taiji quan training on self-efficacy, sleep quality, mood, and physical performance of college students. J Bodyw Mov Ther. 2009;13(2):155-63.

31. Baloh RW, Spain S, Socotch TM, Jacobson KM, Bell T. Posturography and balance problems in older people. J Am Geriatr Soc. 1995;43(6):638-44.

32. Prieto TE, Myklebust JB, Hoffman RG, Lovett EG, Myklebust BM. Measures of postural steadiness: Differences between healthy young and elderly adults. IEEE Trans Biomed Eng. 1996;43(9):956-66.

33. Perrin PP, Jeandel C, Perrin CA, Béné MC. Influence of visual control, conduction, and central integration on static and dynamic balance in healthy older adults. Gerontology. 1997;43(4):223-31.

34. Doumas M, Krampe RT. Adaptation and reintegration of proprioceptive information in young and older adults' postural control. J Neurophysiol. 2010; 104(4):1969-77.

35. Ericksen H, Gribble PA. Sex differences, hormone fluctuations, ankle stability, and dynamic postural control. J Athl Train. 2012;47(2):143-8.

36. Beynnon BD, Bernstein IM, Belisle A, Brattbakk B, Devanny P, Risinger R, et al. The effect of estradiol and progesterone on knee and ankle joint laxity. Am J Sports Med. 2005;33(9):1298-304.

Received: 10/10/2013 Recebido: 10/10/2013

Approved: 04/13/2014 Aprovado: 13/04/2014 